\title{
Microstructure Evolution of Al-Mn-Si-Fe Alloy Studied by In-situ Transmission Electron Mi- croscopy
}

\section{Michaela Poková, Miroslav Cieslar}

Charles University in Prague, Faculty of Mathematics and Physics, Department of Physics of Materials, Ke Karlovu 5, Praha 2, 121 16, Czech Republic

pokova@karlov.mff.cuni.cz, cieslar@met.mff.cuni.cz

Equal channel angular pressing is one of the techniques of severe plastic deformation, which produce materials with sub-micrometric grains. Materials with grains under $1 \mu \mathrm{m}$ are of great importance for industrial applications thanks to enhanced strength at lower temperatures and formability at elevated temperatures. One of the possible ways how to enhance microstructure stability of aluminium alloys at elevates temperatures is addition of small amount of zirconium. In our study, heat treatment at $450{ }^{\circ} \mathrm{C}$ leads to precipitation of $\mathrm{Al}_{3} \mathrm{Zr}$ phase. After ECAP these particles postpone recrystallization above $400{ }^{\circ} \mathrm{C}$. However, in the material without $\mathrm{Al}_{3} \mathrm{Zr}$ particles the recrystallization resistance is comparable thanks to impact of $\alpha-\mathrm{Al}(\mathrm{Mn}, \mathrm{Fe}) \mathrm{Si}$ phases. More over, initial microhardness after ECAP is higher for the alloy, which was not heat-treated at $450{ }^{\circ} \mathrm{C}$ before ECAP, thanks to higher dislocation density and solid solution strengthening by Mn atoms.

Keywords: Aluminium alloys, ECAP, TEM, recrystallization, precipitation.

\section{Acknowledgement}

Financial supports of grants GAUK 1428213, GAČR P107-12-0921 and SVV-2014-260091 are acknowledged.

\section{References}

[1] Z. HORITA, T. FUJINAMI, M. NEMOTO, T. G. LANGDON. (2001). Improvement of Mechanical Properties for Al Alloys Using Equal-channel Angular Pressing. Journal of Materials Processing and Technology 117 288292.

[2] I. NIKULIN, A. KIPELOVA, S. MALOPHEYEV, R. KAIBYSHEV. (2012). Effect of Second Phase Particles on Grain Refinement During Equal-channel Angular Pressing of an Al-Mg-Mn Alloy. Acta Materialia 60 487-497.

[3] J. L. NING, D. M. JIANG, X. G. FAN, Z. H. LAI, Q. C. MENG, D. L. WANG. (2009). Mechanical Properties and Microstructure of Al-Mg-Mn-Zr Alloy Processed by Equal Channel Angular Pressing at Elevated Temperature. Materials Characterization 59 306-311.

[4] Y. IWAHASHI, Z. HORITA, M. NEMOTO, T. G. LANGDON. (1997). An Investigation of Microstructural Evolution During Equal-Channel Angular Pressing. Acta Materialia 45 4733-4741.

[5] M. CABIBBO. (2013). Microstructure Strengthening Mechanisms in Different Equal Channel Angular Pressed Aluminum Alloys. Materials Science and Engineering A 560 413-432.

[6] H. G. KANG, J. P. LEE, M. Y. HUH, O. ENGLER. (2008). Stability against coarsening in ultra-fine grained aluminum alloy AA 3103 sheet fabricated by continuous confined strip sheering. Materials Science and Engineering $A 486$ 470-480.

[7] A. B. NAIZABEKOV, V. A. ANDREYACHSHENKO, R. KOCICH. (2013). Study of deformation behavior, structure and mechanical properties of the AlSiMnFe alloy during ECAP-PBP. Micron 44 210-217.

[8] P. MÁLEK, M. CIESLAR, V. OČENÁŠEK. (2010). Deformation Behaviour of the Al-Mn-Sc-Zr Alloy Produced Using ECAP. Metal 2010 Conference Proceedings.

[9] D. JIANG, J. NING, J. SUN, Z. HU, Y. HOU. (2008). Annealing Behavior of Al-Mg-Mn Alloy Processed by ECAP at Elevated Temperature. Transaction of Nonferrous Metals Society of China 18 248-254.

[10] M. KARLÍK, T. MÁNIK, M. SLÁMOVÁ, H. LAUCHMANN. (2012). Effect of Si and Fe on the Recrystallization Response of Al-Mn Alloys with Zr addition. Acta Physica Polonica A 122 469-474.

[11] M. POKOVÁ, M. CIESLAR, P. MÁLEK. (2014). Twin-Roll Cast Aluminium Alloys Processed by ECAP. Materials Science and Engineering, IOP Conference Series 63012086.

[12] M. VLACH, I. STULÍKOVÁ, B. SMOLA, J. PIESOVÁ, H. CISAŘOVÁ, S. DANIŠ, J. PLÁŠEK, R. GEMMA, D. TANPRAYOON, V. NEUBERT. (2012). Effect of cold rolling on precipitation processes in Al-Mn-Sc-Zr alloy. Materials Science and Engineering A 548 27-32 
[13] J. L. NING, D. M. JIANG. (2007). Influence of Zr addition on the microstructure evolution and thermal stability of Al-Mg-Mn alloy processed by ECAP at elevated temperature. Materials Science and Engineering A 452-453 552-557.

[14] P. MÁLEK, K. TURBA, M. CIESLAR. (2010). High-temperature Deformation Characteristics of ECAP Al-based Alloys Stabilized by Sc+Zr. Nanocon 2010 Conference Proceedings 523-528.

[15] K. TURBA, P. MÁLEK, M. CIESLAR. (2007). Superplasticity in a Zr and Sc Modified AA7075 Aluminium Alloy Produced by ECAP. Kovové Materiály 45 165-170.

[16] M. POKOVÁ, M. CIESLAR, J. LACAZE. (2012). The Influence of Pre-deformation on Minority Phases Precipitation in Modified AW-3003 Aluminium. Metal 2012 Conference Proceedings 1149-1155.

[17] M. POKOVÁ, M. CIESLAR, J. LACAZE. (2012). TEM Investigation of Precipitation in Al-Mn Alloys with Addition of Zr. Manufacturing Technology 13 212-217.

[18] M. POKOVÁ, M. CIESLAR, J. LACAZE. (2012). The Influence of Silicon Content on Recrystallization of TwinRoll Cast Aluminum Alloys for Heat Exchangers. Acta Physica Polonica A 122 625-629.

[19] Y. BIROL. (2009). Response to annealing treatment of a twin-roll cast thin AlFeMnSi strip. Journal of Materials Processing Technology 209 506-510.

[20] A. P. ZHILYAEV, D. L. SWISHER, O. OH-ISHI, T. G. LANGDON, T. R. MCNELLEY. (2006). Microtexture and microstructure evolution during processing of pure aluminum by repetitive ECAP. Materials Science and Engineering A 429 137-148.

[21] M. POKOVÁ, M. CIESLAR, J. LACAZE. (2011). Enhanced AW3003 Aluminum Alloys for Heat Exchangers. WDS'11 Proceedings of Contributed Papers, Part III 141-146.

[22] M. CIESLAR, M. SLAMOVA, M. HAJEK, J. VESELY. (2008). Effect of Thermomechanical Pretreatment on Mechanical Properties of Modified Al-Mn-Fe-Si Based Alloys. Materials Science Forum 567-568 325-328.

[23] X. HUANG, N. HANSEN, N. TSUJI. (2006). Hardening by Annealing and Softening by Deformation in Nanostructured Metals. Science 312 249-251.

[24] M. POKOVÁ, M. CIESLAR, M. SLÁMOVÁ. (2009). The influence of dispersoids on recrystallization of aluminium alloys. International Journal of Materials Research 100 391-394.

[25] O. ENGLER. (1998). On the Influence of Dispersoids on the Particle Stimulated Nucleation of Recrystallization in an Al-Fe-Si Model Alloy. Materials Science Forum 273-275 483-488. 